\section{PENDAMPINGAN PSIKOSOSIAL DAN MODUL PEMBELAJARAN SEKOLAH DASAR UNTUK MENGATASI LEARNING LOSS}

Mufarrihul Hazin'*, Syarif Hidayat², Agus Suherman Tanjung ${ }^{3}$ Ahmad Syamwiel $^{4}$, Abdul Hakim ${ }^{5}$

'STAI Ma'had Aly Al-Hikam, Malang,

${ }^{2}$ Universitas Jayabaya Jakarta,

${ }^{3,5}$ Universitas Nasional Jakarta,

${ }^{4}$ Universitas Negeri Jakarta

*Corresponding author

Email: mufarrihulhazin@gmail.com

\begin{abstract}
Covid-1 9 has made significant changes in the education world, especially in the process of teaching and learning activities, a result of curriculum changes and the compaction of learning materials, the potential of children, especially those in disadvantaged, frontier, and outermost (3T) areas of Indonesia Might lose their right to learn, this causes learning loss. This program aims to help elementary school students in $3 T$ and non $3 T$ areas to get good education quality rights during the Covid-19 Pandemic. The method used in the mentoring model is PAR (Participatory Action Research). The target of this assistance consists of 5 schools in Musi Rawas Utara, SDN I Maur, SDN 3 Maur, SDN Batu Gajah, SDN Bingin Rupit Ulu, SDN Tanjung Beringin. The results of the mentoring of this Program are; I) Initial assessment related to learning difficulties during Covid-19 and the models and strategies used by teachers in the process of teaching and learning activities, 2) Implementation of psychosocial assistance for teachers, students, and parents through home visits and invitations to schools 2) Assisting learning modules in the form of two components, namely the literacy and numeracy modules, activities in the form of assistance to teachers, parents and students throughout learning activities at school and visits to parents and students.

Keywords: Psychosocial Assistance, Learning Modules Assistance, Learning Loss, Elementary School
\end{abstract}

\begin{abstract}
Abstrak
Covid-19 memberikan perubahan besar dalam dunia pendidikan, khususnya dalam proses kegiatan belajar mengajar. Akibat dari perubahan kurikulum dan pemadatan materi pembelajaran menjadikan potensi anak-anak terutama yang berada di daerah tertinggal, terdepan dan terluar (3T) Indonesia untuk kehilangan hak belajar atau learning loss. Tujuan program ini untuk membantu peserta didik Sekolah Dasar di daerah 3T untuk mendapatkan hak-hak pendidikan yang berkualitas di masa Pandemi Covid19 dan mengatasi terjadinya learning loss. Metode pendampingan yang digunakan yaitu metode dalam cara kerja PAR (Participatory Action Research). Sasaran pendampingan ini terdiri dari 5 sekolah di Kabupaten Musi Rawas Utara Sumatera Selatan yaitu SDN I Maur, SDN 3 Maur, SDN Batu Gajah, SDN Bingin Rupit Ulu, SDN Tanjung Beringin. Hasil pendampingan program ini adalah; I) Asesmen awal terkait kesulitan pembelajaran selama covid- 19 serta model dan strategi yang digunakan oleh guru dalam proses kegiatan belajar mengajar, 2) Terlaksananya pendampingan psikososial bagi guru, siswa dan orang tua melalui home visit dan undangan ke sekolah 3) Pendampingan modul pembelajaran berupa dua komponen yaitu modul literasi dan numerasi kegiatannya berupa pendampingan kepada guru, orang tua dan siswa memalui kegiatan pembelajaran di sekolah dan kunjungan orang tua dan siswa.

Kata Kunci: Pendampingan Psikososial, Modul pembelajaran, Learning Loss, Sekolah
\end{abstract}


Pendampingan Psikososial dan Modul Pembelajaran Sekolah Dasar untuk mengatasi Learning Loss

Mufarrihul Hazin, Syarif Hidayat, Agus Suherman Tanjung, Ahmad Syamwiel, Abdul Hakim

Volume 1, No. 2, Agustus 2021 hal. 178-189

DOI Artikel : 10.46306/jub.v1i2.34

\section{PENDAHULUAN}

Pandemi Covid-19 telah tersebar diseluruh dunia secara mereta. Di Indonesia jumlah kasus COVID-19 menunjukan peningkatan yang drastis. Upaya pemerintah dalam penanganan pandemi ini terus dilakukan, namun belum ada dampak yang siginifikan. Akhirnya melumpuhkan segala aspek di Indonesia bahkan dunia. Seluruh segmen terganggu, begitu juga dalam sector pendidikan (Syah, 2020). Salah satu aspek yang paling terdapampak dalam pendidikan adalah kegiatan belajar mengajar.

Kondisi Pandemi Covid-19 menghalangi untuk melakukan proses pembelajaran secara normal. tidak memungkinkan kegiatan belajar mengajar berlangsung secara normal. Hala ini dalam rangka mencegah penyebaran covid-19 yang lebih luas, akhirnya ribuan sekolah dan perguruan tinggi ditutup dan para siswa melakukan pembelajaran dari rumah, dan lebih dari empat juta guru mengajar dilakukan secara jarak jauh via daraing. Kondisi ini terjadi di Indonesia yang setidaknya $97 \%$ siswa tidak lagi belajar di sekolah demi mencegah penyebaran wabah (Zamjani, dkk., 2020).

Pembelajaran dari rumah selama pandemi covid-19 mengakibatkan dampak yang dahsyat dan luarbiasa. Apalagi di Indonesia, hal ini bukan hal yang mudah, karena digitalisasi pendidikan belum merata dan baru akan mulai berjalan. Namun, seluruh institusi pendidikan dipaksa bertransformasi dan beradaptasi dengan pembelajaran yang dilakukan secara online (Basar, 202I).

Dampak yang terjadi dengan adanya pembelajaran jarak jauh yaitu sulitnya memantau perkembangan peserta didik secara langsung. Hal ini tentunya mempengaruhi pada aspek psikologis dan sosial guru, siswa, bahkan juga orang tua. Tekanan mental akibat beratnya tugas dirasakan oleh siswa, dan orang tua yang juga harus mendampingi proses pembelajaran merasakan kesulitan. Begitu juga gurunya dengan beban yang bertambah, karena harus mempersiapkan perangkat pembelajaran lebih baik, seperti membuat video tutorial, absen daring, bahkan penilaian melalui online. Hal ini semua berdampak pada kondisi psikososial komponen pendidikan tersebut (Aslamiyah \& Nurhayati, 202I).

Akibat pembelajaran daraing dan kurangnya infrastruktur pembelajaran daring, hal ini bukan saja mengakibatkan dampak psikososial bagi siswa, namun hal ini tentunya juga mengakibatkan hilangnya kompetensi yang didapatkan oleh peserta didik atau yang dikenal dengan sebutan learning loss.

Berbagai kajian menyebutkan bahwa Learning loss refers to "any specific or general loss of knowledge and skills or to reversals in academic progress, most commonly due to extended gaps or discontinuities in a student's education" (Huong \& Jatturas, 2020). Sedangkan menurut Pratiwi, dkk (2020) menyebuatkan bahwa Learning loss adalah hilangnya pengetahuan dan keterampilan siswa dalam bidang akademik akibat terputusnya akses pendidikan. Learning loss di Indonesia terjadi karena rendahnya kualitas guru dalam memanfaatkan teknologi ketika proses pembelajaran.

Untuk mengantisipasi kendala tersebut, Pemerintah berusaha keras mebuat berbagai macam kebijakan, yaitu memberlakukannya kurikulum darurat, dimana pembelajaran difokuskan pada pembelajaran yang memperkuat aspek literasi, numerasi, sains dan pendidikan karakter. Selain itu, pemerintah menerbitkan SKB 4 menteri; Menteri Pendidikan Dan Kebudayaan, Menteri Agama, Menteri Kesehatan, dan Menteri Dalam Negeri Republik Indonesia yang isisnya melakukan penyesuaian terkait daerah yang dapat melakukan tatap muka, yakni di zona kuning dan hijau dengan penerapan protokol kesehatan yang ketat.

Dalam rangka menindaklanjuti beberapa kebijakan terkait kurikulum darurat dan protocol melaksanakan pembelajaran tatap muka, Kementerian Pendidikan Dan Kebudayaan pada tahun 2020 membuat modul pembelajaran yang digunakan untuk guru, siswa dan pendampingan untuk orang tua. $\mathrm{Hal}$ ini untuk menjawab perubahan kurikulum dan pemadatan materi pembelajaran. Minimnya sarana menjadikan hambatan dalam proses belajar, seperti sulitnya sinyal internet, dan keterbatasan kapasitas orangtua mendampingi anak belajar sehingga anak-anak tidak belajar secara optimal. 
Pendampingan Psikososial dan Modul Pembelajaran Sekolah Dasar untuk mengatasi Learning Loss

Mufarrihul Hazin, Syarif Hidayat, Agus Suherman Tanjung, Ahmad Syamwiel, Abdul Hakim

Volume 1, No. 2, Agustus 2021 hal. 178-189

DOI Artikel : 10.46306/jub.v1i2.34

Mengatasi masalah tersebut, pada tahun 2020 Direktorat Sekolah Dasar Kemdikbud mencanangkan program kejar mutu berupa pendampingan terhadap Sekolah Dasar di Daerah 3T dan Non-3T serta wilayah terdampak Selama Masa Pandemi Covid-19.

Dengan demikian, untuk mengptimalkan program Direktorat SD Kemendikbud, maka Pimpinan Pusat IPNU yang fokus bergerak pada bidang pendidikan bersama Tim dari Dosen dan Mahasiswa Magister di Indonesia membuat pengabdian kepada masyarakat untuk mensukseskan program tersebut. Tujuan dari pengabdian masyarakat ini adalah membantu peserta didik, guru dan orang tua dalam meningkatkan kualitas pembelajaran jarak jauh di masa pandemi dan mengatasi learning loss.

\section{METODE PENGABDIAN}

Metode yang diguankan dalam pengabdian masyarakat ini adalah PAR (Participatory Action Research). Metode PAR sudah sangat popular digunakan dalam proses pengabdian kepada masyarakat. Hal ini dikarenakan dalam metode PAR melibatkan secara aktif semua pihak/ stakeholders dalam mengkaji tindakan yang akan dan sedang berlangsung untuk melakukan perubahan yang berlandasankan gagasan dari rakyat/ buttom menuju kearah yang lebih baik. (Noviana, 20l0).

Pendampingan ini menggunakan Langkah-langkah sebagai berikut; to know (mengetahui kondisi riil komunitas), to understand (memahami problem komunitas), to plan (merencanakan pemecahan masalah komunitas), to action (melakukan program aksi), to reflection (penyadaran).

Adapun strategi pendampingan dapat dilakukan melalui beberapa metode sebagai berikut; Peer Coaching, Fun Learning, Spiritual Approach, Acitivity - Based Learning, Psicosocial.

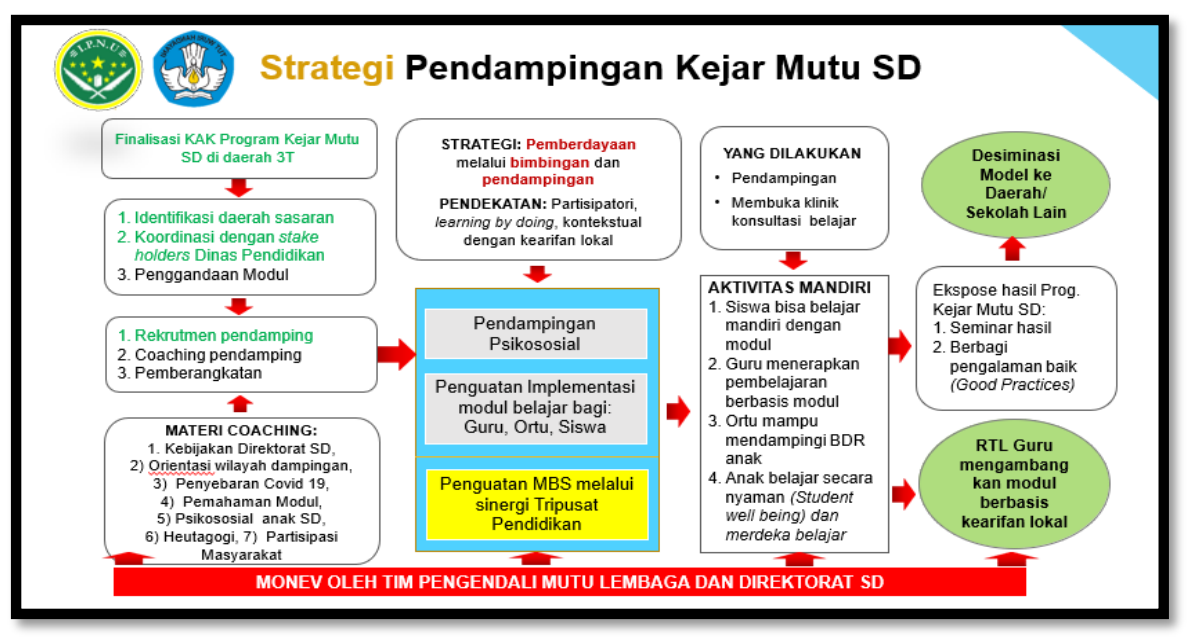

Gambar I. Strategi Pengabdian Kepada Masyarakat

Pengabdian Kepada masyarakat berupa pendampingan psikososial dan penguatan modeul pembelajaran dilakukan di 5 sekolah yaitu SDN I Maur, SDN 3 Maur, SDN Batu Gajah, SDN Bingin Rupit Ulu, SDN Tanjung Beringin. Kelima sekolah tersebut berada di Kabupaten Musi Rawas Utara. Lama waktu yang digunakan yaitu dua bulan yaitu terhitung pada tanggal I I November 2020 hinggan I I Januari 2021.

\section{PELAKSANAAN DAN PEMBAHASAN}

Hasil kegiatan yang diraih oleh tim pengabdian dan fasilitator selama melakukan program pendampingan. Terdapat tiga kegiatan inti, yaitu; kegiatan identifikasi masalah pendidikan, kegiatan pendampingan psikososial, pendampingan penguatan implementasi modul. Outcome yang diperoleh adalah adanya peningkatan mutu pada sekolah dasar yang dilakukan proses pendampingan program, 
Pendampingan Psikososial dan Modul Pembelajaran Sekolah Dasar untuk mengatasi Learning Loss

Mufarrihul Hazin, Syarif Hidayat, Agus Suherman Tanjung, Ahmad Syamwiel, Abdul Hakim

Volume 1, No. 2, Agustus 2021 hal. 178-189

DOI Artikel : 10.46306/jub.v1i2.34

khususnya bagi kelima sekolah sebagai piloting dan umumnya bagi sekolah dasar yang ada di seluruh kabupaten musi rawas utara. Hal ini tergambar dari strategi kegiatan kejar mutu sebagai berikut.

\section{Identifikasi Masalah}

Kegiatan identifikasi masalah pendidikan dilakukan dengan metode mini survai yang dilakukan pada objek 24 I responden dilihat dari klasifikasi berdasarkan jabatan yaitu guru sebanyak $12,4 \%$, orang tua/wali siswa sebanyak 32,4\%, kepala sekolah sebanyak $0,8 \%$ dan murid sebanyak $12,4 \%$.

Identifikasi pertama; yaitu tentang persepsi responden terhadap kegiatan belajar mengajar selama Pandemi Covid-19 yang dilaksanakan secara Luring (Luar Jaringan) sebanyak 88,8\%, Daring (Dalam Jaringan) sebanyak 0\% dan Gabungan Luring Daring sebanyak II,2\%.

Identifikasi Kedua; yaitu persepsi responden terhadap kegiatan belajar mengajar selama Pandemi Covid-19 yang dilaksanakan secara Luring (Luar Jaringan) dan bagaimana cara materi pembelajaran yang diberikan oleh sekolah, (I) Orang tuan mengambil tugas di sekolah sebanyak 6,4\%, (2) Guru mengirimkan materi ke siswa sebanyak 49,3\%, (3) Siswa mengambil tugas ke sekolah sebanyak $34,2 \%$, (4) Guru kerumah dan secara gantian siswa kerumah guru sebanyak 4,4\%, (5) Tugas di LKS sebanyak I,5\%, (6) Bergantian kadang Luring- Kadang daring sebanyak I,5\%. Jadi lebih banyak Guru mengirimkan materi ke siswa.

Identifikasi Ketiga; yaitu tentang persepsi responden terhadap kegiatan belajar mengajar selama Pandemi Covid-19. Dari hasil menunjukakan bahawa; 85,5\% menjawab tidak baik, 8,3\% menjawab baik. dan lainnya tidak menjawab. Dari hasil tersebut menunjukan bahwa menurut para responden, kegiatan belajar mengajar selama pandemi ini tidak berjalan dengan baik.

Identifikasi Keempat terkait dengan kesulitan guru dalam pelaksanaan kegiatan belajar dari rumah selama pandemi covid-19. Dari hasil tersebut $96,3 \%$ responden berpendapat ada kesulitan dan $3,7 \%$ mengatakan tidak ada. Hasil tersebut menunjukan bahwa adanya kesulitan guru untuk melakukan proses mengajar selama masa pandemi Covid-19.

Identifikasi Kelima, terkait dengan kesulitan guru dalam mendampingi anak selama kegiatan belajar dari rumah selama pandemic covid-19. Dari hasil yang didapatkan $96,3 \%$ responden menjawab ada kesulitan dan 3,7\% menjawab tidak ada. Hal ini menunjukan bahwa orang tua mengalami kesulitan dalam melakukkan pendampingan kepada anaknya dalam kegiatan belajar di rumah.

Identifikasi Keenam, terkait dengan kesulitan orang tua dalam mendampingi anak selama kegiatan belajar dari rumah selama pandemic covid-19. Dari hasil yang didapatkan $95,4 \%$ responden menjawab ada kesulitan dan 4,64\% menjawab tidak ada. Hal ini menunjukan bahwa orang tua mengalami kesulitan dalam melakukkan pendampingan kepada anaknya dalam kegiatan belajar di rumah.

Identifikasi ketujuh, tentang pelibatab SDM yang berpotensi di masyarakat untuk mendukung pelaksanaan pendampingan peserta didik selama masa pandemi Covid-19. Dari seluruh responden tersebut 34\% menjawab ada keterlibatan SDM yang berpotensi dan $66 \%$ menjawab tidak ada pelibatan SDM yang berpotensi di masyarakat untuk mendukung pelaksanaan pendampingan peserta didik.

Identifikasi kedelapan, materi belajar disesuaikan dengan kondisi pandemi Covid-19. Hasil yang didapatkan $78,4 \%$ menjawab adanya penyesuaian materi belajar dan $21,6 \%$ menjawab tidak ada penyesuaian.

Identifikasi kesembilan, tentang materi/buku yang diberikan selama kegiatan belajar dari rumah. $88 \%$ responden merasa berat terhadap materi yang diberikan dan $12 \%$ menjawab tidak berat terhadap materi yang diberikan. Hal ini menunjukan bahwa materi/buku yang diberikan selama belajar di masa pandemi Covid-1 9 merasa berat terhadap materi tersebut.

Identifikasi kesepuluh, komunikasi rutin antara guru dengan orang tua terkait dengan kegiatan belajar selama pandemic covid-19.6I,4\% responden menjawab bahwa ada komunikasi yang terjalin antar 
Pendampingan Psikososial dan Modul Pembelajaran Sekolah Dasar untuk mengatasi Learning Loss

Mufarrihul Hazin, Syarif Hidayat, Agus Suherman Tanjung, Ahmad Syamwiel, Abdul Hakim

Volume 1, No. 2, Agustus 2021 hal. 178-189

DOI Artikel : 10.46306/jub.v1i2.34

guru dan orang tua sedangkan $38,6 \%$ menjawab tidak adanya komunikasi yang terjadi. Dari hasil tersebut dapat disimpulkan bahwa perlu ditingkatkan akan komunikasi yang bai kantar guru dan orang tua.

Identifikasi kesebelas, tentang adanya pemantauan terhadap pelaksanaan Belajar dari rumah selama Pandemic Covid- I9? Yang menjawab lya 75,9\% responden dan 24, I\% mengatakan tidak adanya Pemantauan.

Identifikasi kedua belas, strategi untuk mengurangi rasa jenuh (strees) siswa selama kegiatan BDR. 56,4\% responden mengatakan ada strategi untuk mengurangi rasa jenuh siswa dan 43,6\% responden mengatakan tidak ada.

Identifikasi ketiga belas, Apakah ada bantuan khusus untuk orang tua yang mengalami kesulitan dalam pendampingan. 65,1\% responden mengatakan lya ada bantuan khusus untuk orang tua yang mengalami kesulitan dalam pendampingan dan $34,9 \%$ responden mengatakan tidak ada. Hal ini menunjukan perlu adanya identifikasi secara menyeluruh atas orang tua yang mengalami kesulitan melakukan pendampingan anaknya dalam kegiatan belajar dari rumah.

\section{Pendampingan Psikososial}

Rangkaian pelaksanaan program pengabdian yaitu pendampingan psikososial. Dampak pandemi covid-1 9 yang begitu besar perlu adanya pendampingan dan penguatan untuk mengembalikan semangat dan motivasi para pihak. Hal ini sesuai dengan pendapat Savy (2018) yang mengakan bahwa “pendampingan psikososial merupakan paduan antara penanganan psikologis dan penanganan sosial. Perpaduan ini menyatukan anatara penanganan psikologis yang bertumpu pada pemahaman interpersonal korban dengan persoalan sosial budaya yang melingkupi kehidupan korban".

Demikian pula dengan dunia pendidikan begitu besar yang menjadi sasaran atas dampak adanya pandemic covid-19 diantaranya adalah pihak sekolah. Dalam dunia sekolah, ada 3 komponen penting yang harus segera mendapatkan pelayanan dan pemulihan akibat dampak pandemi, yaitu guru, siswa, dan orang tua.

\section{Pendampingan psikososial bagi guru}

Pelaksanaan pendampingan psikosial bagi guru yang dilakukan oleh tim pengabdian kepada masyarakat dilaksanakan setelah melakukan asesmen/identifikasi masalah pendidikan khususnya di saat pandemi. Banyak para guru yang mengeluhkan kondisi pandemi, karena tidak lagi dapat melakukan proses KBM (Kegiatan Belajar Mengajar) sebagaimana mestinya. Banyak tuntutan yang harus dikerjakan oleh guru, mulai dari membuat perangkat pembelajaran.

Berbagai kegiatan pendampingan psikososial khusus kepada guru dilakukan oleh tim baik di sekolah maupun dirumah, baik secara kelompok maupun individu. Bahkan pendampingan kepda guru juga dilakukan menggunakan motode peer teaching. Metode ini gunakan untuk para guru dapat memberikan motivasi dan berdiskusi terkait model pembelajaran yang tepat.

Pendampingan psikososial terhadap guru menjadi hal utama, karena guru adalah ujung tombak dari pendidikan terutama dalam proses kegiatan pembelajaran di sekolah (Murtadlo \& Hazin, 20।8). Dengan demikian, maka berbagai pola dilakukan oleh tim untuk melakukan penguatan psikologi dan mental guru, bukan hanya secara kelompok namun juga individu. Sebagaimana gambar berikut ini. 


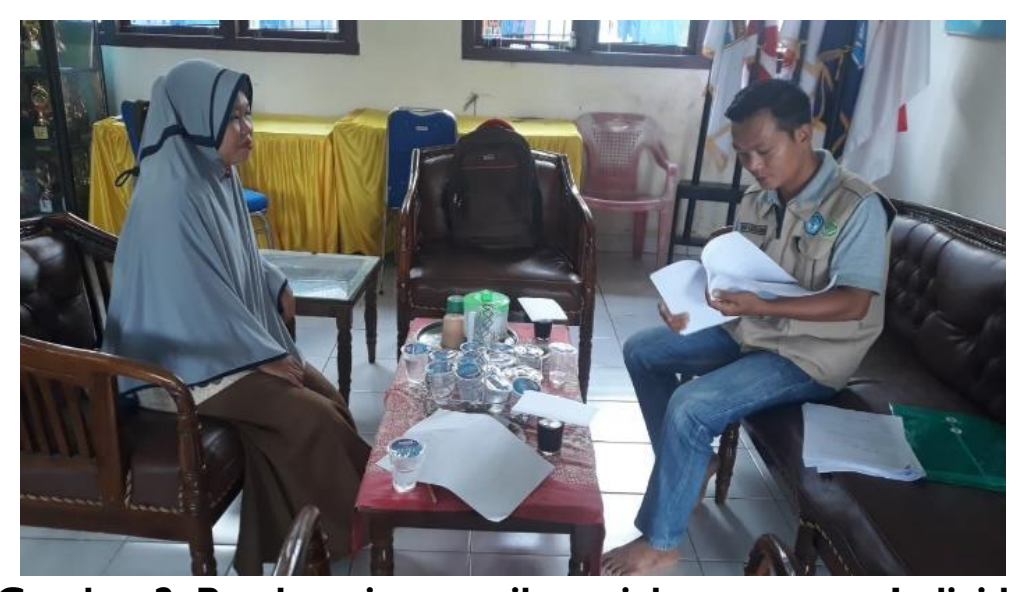

Gambar 2. Pendampingan psikososial guru secara Individu

Pendampingan psikososial kepada guru harus dilakukan agar guru dalam menghadapi pembelajaran tidak stress dan mental tetap terjaga. Menurut Dicky (2020) "situasi kedaruratan dapat menimbulkan gangguan kesehatan mental yang ringan hingga berat di kalangan mereka yang terdampak secara langsung". Dengan demikian, proses pembelajaran selama ini yang menimbulkan keterbatasan, kejenuhan dan kebosanan para guru bisa teratasi dengan adanya pendampingan.

\section{Psikososial Terhadap Siswa}

Siswa menjadi bagian besar yang terdampak covid-19 terutama dalam kegiatan belajar mengajar, terdapat beberapa masalah yang dihadapi oleh para siswa, diantaranya; mereka tidak dapat belajar seperti biasanya, karena aturannya dibatasi. Mereka tidak dapat bertemu teman teman dan bersosialisasi seperti biasanya. Hal ini yang membuat tekanan psikologis dan juga kurangnya bersosialisasi dengan kawan dan gurunya. Hal ini dibutuhkan adanya pendamping guna mengatasi berbagai masalah psikologi dan juga sosial siswa.

Pendampingan psikososial bagi siswa ini untuk menjaga kondisi psikologi dan sosial pad anak. Hal ini sebagaimana yang dikemukakan oleh Kementerian Pemberdayaan Perempuan Dan Perlindungan Anak (2019) "Dukungan psikososial menggunakan pendekatan yang menekankan pada pemahaman adanya hubungan yang dinamis antara aspek psikologis dan sosial seseorang, dimana kedua aspek tersebut saling terkait dan mempengaruhi." Hal ini yang dilakukan oleh tim terhadap anak dalam melakukan pendampingan.

Berdasarkan pendekatan tersebut, pendampingan psikososial terhadap siswa bukan hanya sekedar dilakukan di rumah masing-masing namun juga ada yang berkelompok dan di sekolah denagn menggunakan berbagai macam metode dan strategi peningkatan psikososial anak.

Kegiatan pendampingan psikososial, bukan hanya dilakukan di dalam kelas, ketika di sekolah tim pengabdian juga melakukan kegiatan outbond sebagai bentuk kegiatan menambah motivasi dan inspirasi semanagat untuk anak. Selain itu berbagai permainan edukatif juga dilakukan permainan yang dapat meningkatkan motivasi dan kepercayaan diri (aspek psikologis); dan kekompakan dan kerja tim (aspek sosial). 


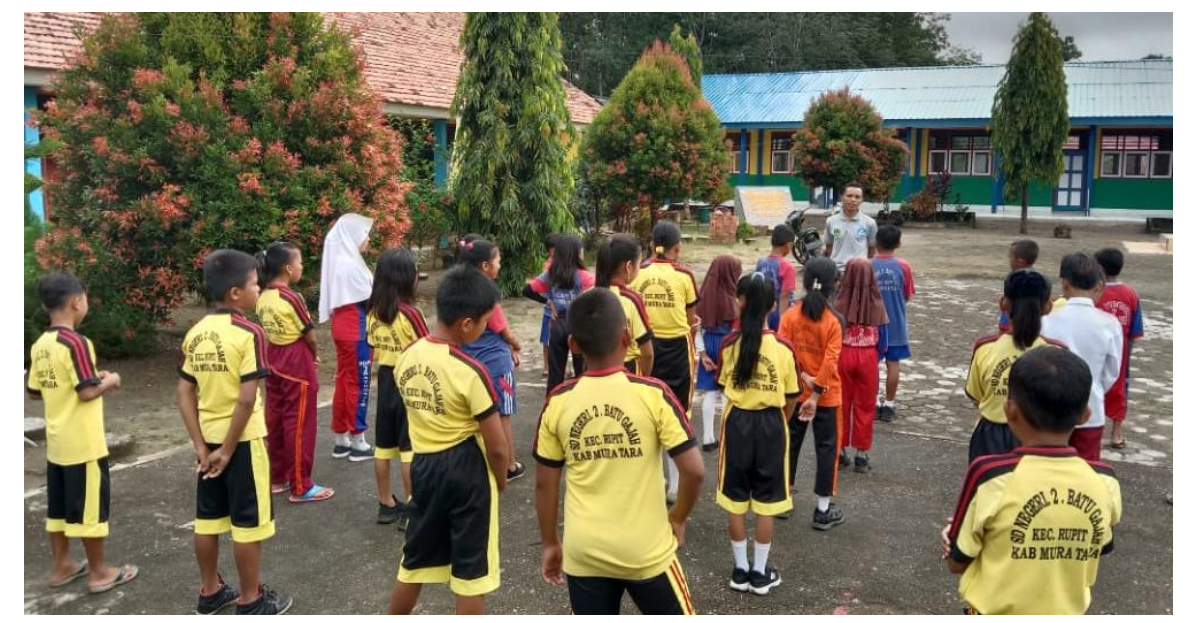

Gambar 3. Psikososial melalaui kegiatan outbond siswa

Kegiatan outbond menjadi salah satu kegiatan psikososial yang dapat dilakukan dan dikembangkan salah satunya melalui Penjaskes (pendidikan jasmani dan olahraga). Hal ini sesuai dengan pendapat Freeman (Nopembri, 20I4) bahwa "olahraga menunjukkan tiga pola, yaitu: merefleksikan budaya dan masyarakat, mempertebal perbedaan psikososial, dan merupakan sebuah wahana untuk konflik psikososial." Lebih lanjut Coakley (200I) berpendapat bahwa olahraga tidaklah sekedar permainan dan juga pertandingan semata, namun juga terdapat fenomena psikososial yang memiliki arti dan makna lebih jauh dari sekedar skor dan juara.

\section{Psikososial terhadap orang tua}

Pendidikan yang berhasil adalah pendidikan yang mendapatkan dukungan dari berbagai pihak terutama para orang tua/ wali murid. Pendampingan psikososial terhadap orang tua dilakukan dengan berbagai pola, diantara yaitu orang tua dikumpulkan di sekolah. Hal ini dilakukan karena orang tua perlu mengetahui dan memahami bahwa begitu besar peran orang tua dalam mendidik anaknya. Pendidikan anak bukan hanya sekedar tanggungjawab guru dan sekolah, namun perlu adanya sinergi yang baik dengan orang tua.

Dengan demikian, penting bagi tim pengabdian untuk melakukan pendampingan psikososial kepada orang tua agar tetap peduli terhadap pendidikan dan memahami pentingnya dunia pendidikan. Berbagai pola pendampingan dilakukan baik diaundang ke sekolah mapun ke rumah.

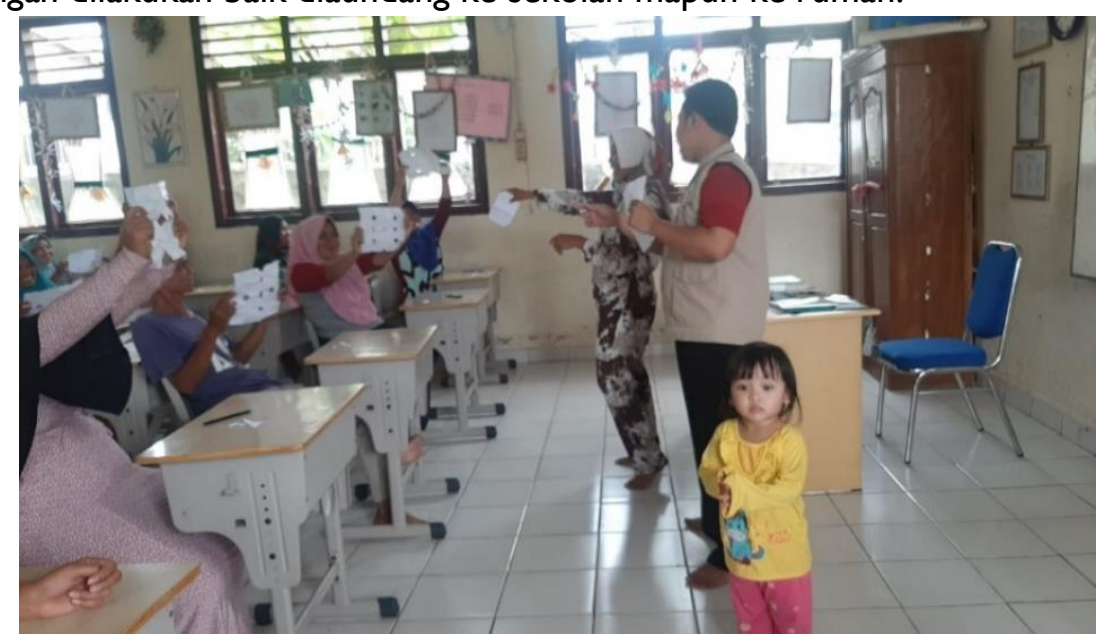

Gambar 4. Pendampingan psikososial bagi orang tua

Pendampingan psikososial menjadi sangat penting, karena selain mendengarkan dari sisi anak, cobalah lakukan kontak rutin dengan guru, untuk menanyakan perkembangan anak di sekolah. Apakah 
Pendampingan Psikososial dan Modul Pembelajaran Sekolah Dasar untuk mengatasi Learning Loss

Mufarrihul Hazin, Syarif Hidayat, Agus Suherman Tanjung, Ahmad Syamwiel, Abdul Hakim

Volume 1, No. 2, Agustus 2021 hal. 178-189

DOI Artikel : 10.46306/jub.v1i2.34

ada masalah yang mungkin tidak kamu ketahui, atau seperti apa kemampuan anak ketika menyerap materi yang disampaikan guru.

$\mathrm{Hal}$ ini sesuai dengan pendapat Kholil (2020) bahwa "mendampingi anak belajar online, menjadi tantangan dan keistimewaan tersendiri, dan yang paling perlu diperhatikan adalah orang tua di rumah bukan untuk menggantikan semua peran guru di sekolah, melainkan hanya membantu semampunya. Selain itu, orang tua juga dituntut untuk menciptakan lingkungan kondusif, memberikan inspirasi dan motivasi dalam belajar, membantu unruk memahamkan materi dan membantu pengerjaan tugas-tugas (Yuliarisma, 202I).

\section{Pendampingan Modul Pembelajaran SD}

Dalam pengabdian kepada masyarakat, kegiatan selain pendampingan psikososial, juga dilakukan pendampingan implementasi modul pembelajaran sekolah dasar. Dalam masa darurat, seperti covid saat ini menuntut untuk selalau dapat beradaptasi dalam pembelajaran. Hal ini dikarenakan keterbatasan sumber daya dan berbagai kendala, baik secara teknis mapun non teknis. Dengan demikian, pembelajaran tidak dapat diberikan secara utuh, dan dibutuh alternatif terbaik dengan difokuskan pada literasi dan numerasi guna mengatasi terjadinya learning loss.

Upaya mengatasi learning loss yang terjadi, Kementerian Pendidikan dan Kebudayaan telah membuat kurikulum darurat dan juga modul pembelajaran Modul pembelajaran yang berfokus pada literasi dan numerasi ini dibuat untuk membantu memfasilitasi pembelajaran jarak jauh yang dilakukan oleh guru, juga untuk membantu orang tua dalam proses mendampingi anaknya belajar di rumah, serta modul ini juga untuk membantu siswa mudah dalam belajar. Dalam modul ini, terfokus pada literasi dan numerasi. Meskipun demikain, KD yang dirujuk dan dijadikan landasan adalah KD dari berbagai mata pelajaran dan diperkuat dengan pendidikan karakter.

\section{Pendampingan Modul terhadap Guru}

Modul pendamping bagi guru, menjelaskan beberapa hal; yaitu terkait pemetaan dan penjabaran KD dan kerangka acuan modul, cara pendistribusian modul, mekanisme memberikan penilaian kinerja siswa sebagai proses umpan balik pembelajaran, dan menjelaskan tentang aktivitas/ kegiatan peserta didik dalam proses pembelajaran selama satu minggu. Hal ini dikarenakan guru harus dapat selalu memantau dan memfasilitasi peserta didik saat belajar dari rumah.

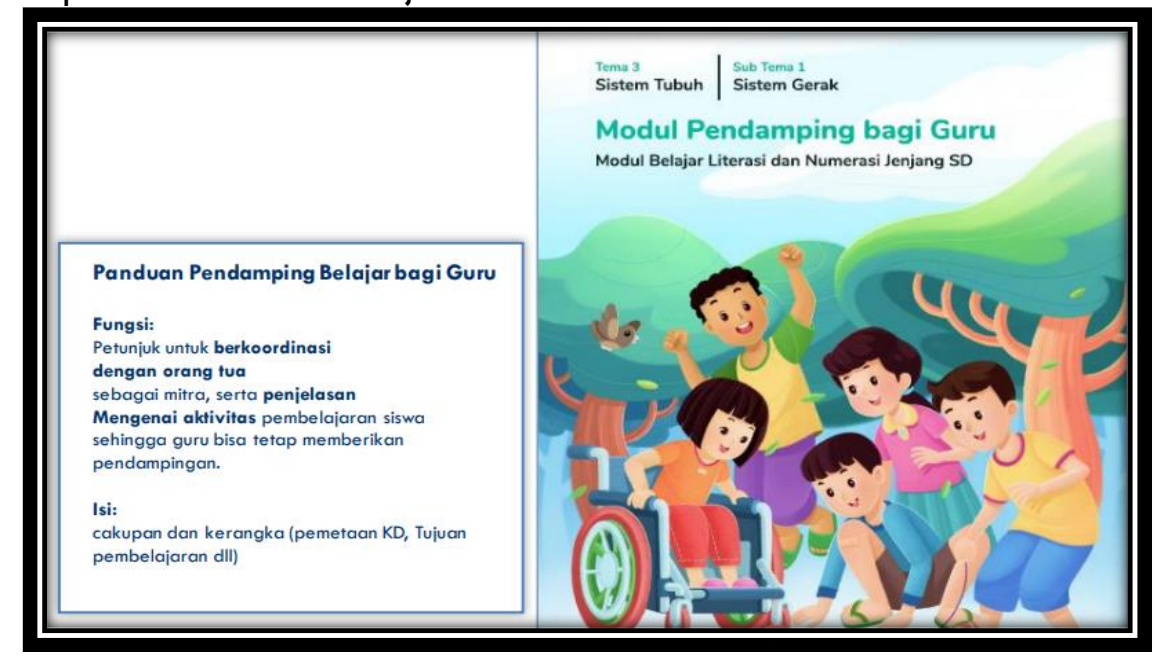

Gambar 5. Modul Pendampingan bagi Guru

Pendampingan kepada guru dalam rangka implementasi modul dilakukan dengan berbagai model dan strategi. Salah satunya yaitu melalaui workshop di sekolah. Kegiatan ini bertujuan agar guru memahami isi modul literasi dan numerasi guru, orang tua, dan siswa. Selain itu juga bertujuan agar guru dapat melakukan pembelajaran tatap muka dengan menggunakan modul dan mendampingi peserta didik dalam mengerjakan modul selama belajar di rumah. 


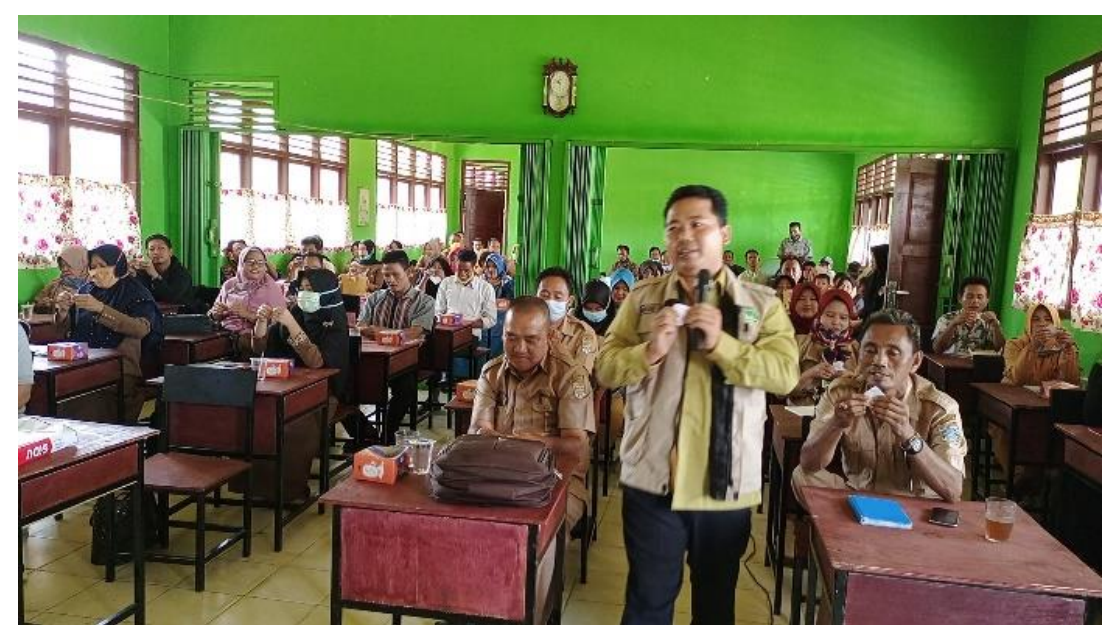

Gambar 6. Workshop pendampingan modul bagi guru

Pendampingan modul kepada guru selain menggunakan model workshop/diklat, dilakukan juga dengan model pembelajaran teman sebaya antar sesama guru. Metode tutor sebaya dilakukan dengan cara memperdayakan kemampuan guru yang memiliki kemampuan tinggi, kemudian guru tersebut mengajarkan materi/ berbagi pengetahuan kepada teman- temannya yang belum paham. Hal ini juga merupakan model yang efektif yang digunakan dalam melakukan pemahaman terhadap implementasi modul pembelajaran.

\section{Pendampingan Modul terhadap Siswa}

Modul belajar bagi siswa, membahas/ berisi tentang pembelajaran yang kontekstual, pembelajaran yang dapat dilakukan siswa dengan pendampingan dari orang tua atau anggota keluarga yang lainnya yang ada dirumah secara online. Modul ini akan membantu siswa mencapai kompetensi literasi dan numerasi pada berbagai mata pelajaran dalam rangka menghindari terjadinya learning loss.

Pendampingan modul terhadap siswa dilakukan secara berkelanjutan. Model yang digunakan ada 2 macam, yaitu pendampingan di sekolah dan pendampingan ke rumah (home visit). Metode yang digunakan banyak menggunakan model project based learning, problem based learning dan contextual learning. Selain itu kami juga melakukan pola peer teaching mereka atar teman se kelas saling memberikan pemahaman masing-masing.

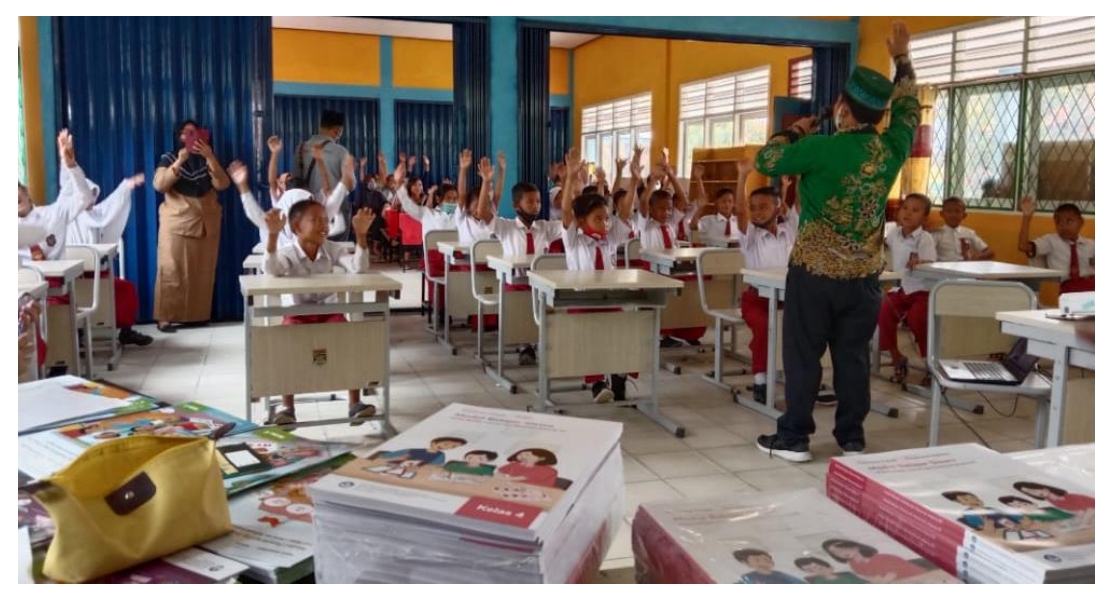

Gambar 7. Pendampingan Modul untu siswa

Pendampingan penguatan modul kepada siswa yang dilakukan di sekolah diperkuat dengan melakukan kunjungan dan pendampingan ke rumah (home visit). Hal ini dikarenakan kegiatan yang dilakukan di sekolah saja kurang maksimal, karena pembelajaran dilakukan dengan mode gabungan antara daring dan luring. 
Pendampingan Psikososial dan Modul Pembelajaran Sekolah Dasar untuk mengatasi Learning Loss

Mufarrihul Hazin, Syarif Hidayat, Agus Suherman Tanjung, Ahmad Syamwiel, Abdul Hakim

Volume 1, No. 2, Agustus 2021 hal. 178-189

DOI Artikel : 10.46306/jub.v1i2.34

\section{Pendampingan Modul terhadap Orang tua}

Peran oraang tua dalam pembelajaran di era pendemi menjadi sangat penting. Pelibatan orang tua dalam proses belajar mengajar begitu terasa. Hal ini dikarenakan proses pembelajarannnya dilakukan di rumah. Peran orang tua dalam mendukung kegiatan pembelajaran online dapat sebagai fasilitator, pembimbing, ataupun guru dan bahkan juga motivator (Khasanah dkk., 202I).

Modul pendampingan untuk orang tua bermuatan/ bersisi tentang tips dan trik dalam mendampingi anak ketika belajar online, tips melakukan kegiatan literasi dan numerasi serta tabel organizer yang merupakan rangkuman dari pembelajaran selama satu minggu. Hal ini tentunya akan memudahkan para orang tua dalam menyiapkan strategi dan keperluan belajar anak dari rumah dalam proses pembelajaran.

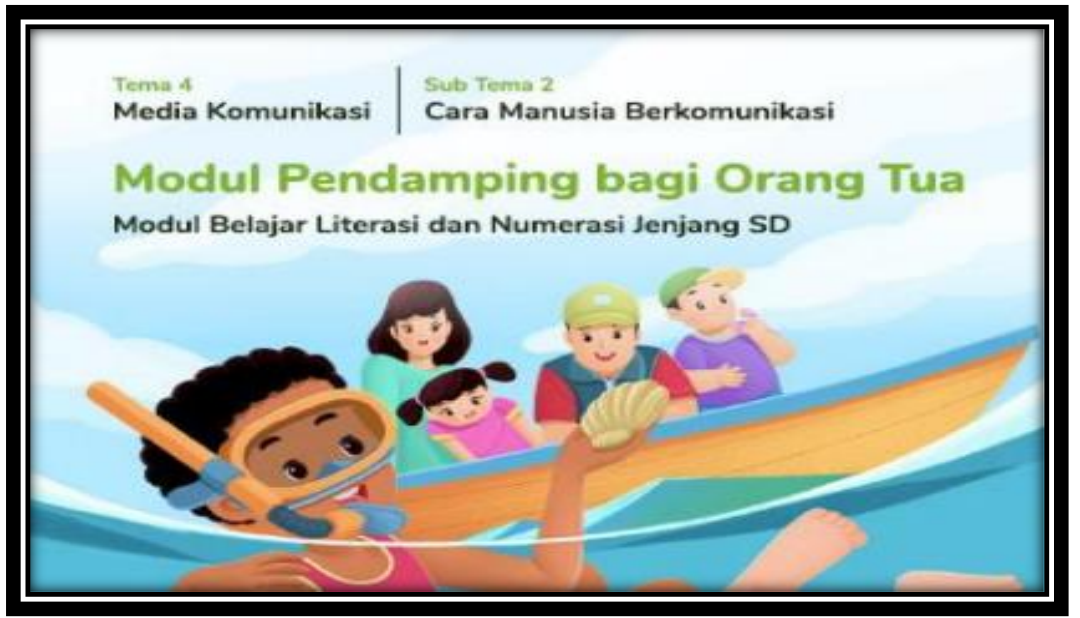

Gambar 8. Modul pendampingan bagi orang tua

Dalam pendampingan implementasi modul literasi dan numerasi bagi orang tua begitu sangat penting karena di dalamnya memuat tentang pedoman dan panduan bimbingan dan pembinaan orang tua terhadap anaknya. Pendampingan modul terhadap orang tua dilakukan dengan berbagai pola, ada pendampingan berupa pengenalan dan pemahaman modul secara bersamaan yang dilakukan dengan mengundang para orang tua ke sekolah.

Selain dilakukan pembinaan dan pemahaman secara komprehensif di sekolah, pendampingan penguatan modul untuk orang tua dilakukan dengan pola home visit (para fasilitator mengunjungi rumah orang tua dan murid). Kegiatan ini menfasilitasi adanya orang tua yang banyak kegiatan berkebun dan Bertani, sehingga aktifitas untuk di undang kesekolah kurang efektif.

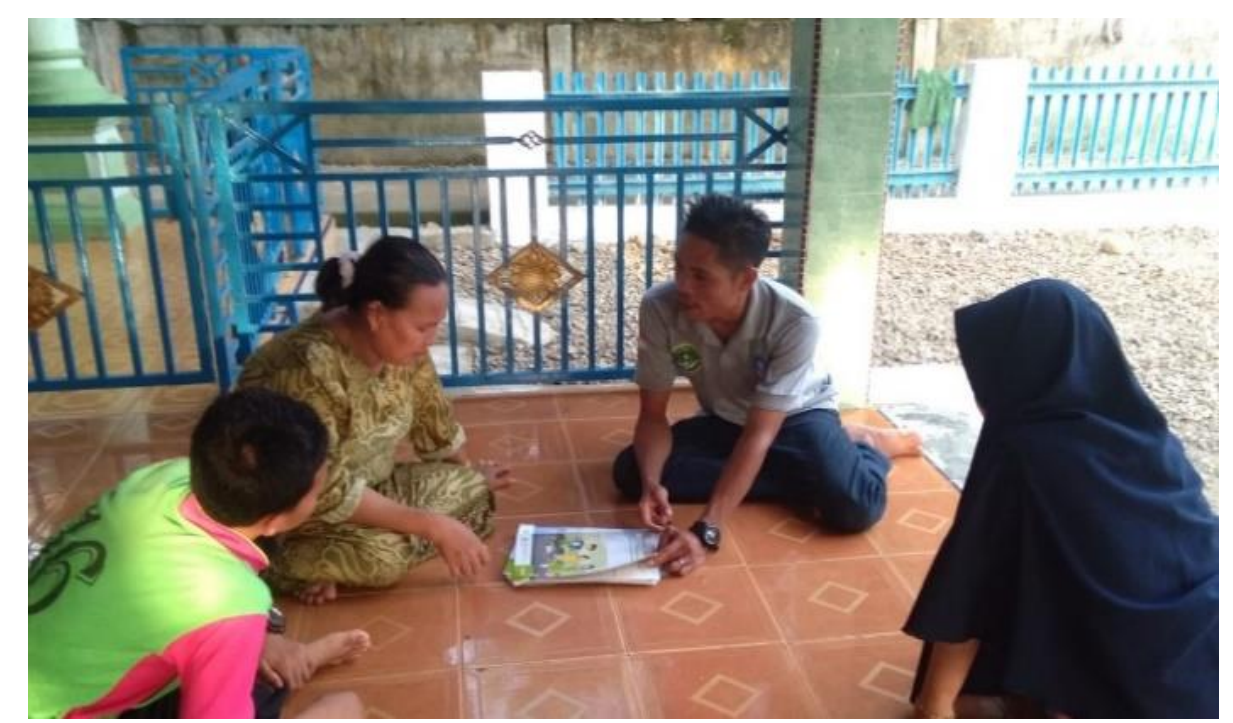


Pendampingan Psikososial dan Modul Pembelajaran Sekolah Dasar untuk mengatasi Learning Loss

Mufarrihul Hazin, Syarif Hidayat, Agus Suherman Tanjung, Ahmad Syamwiel, Abdul Hakim

Volume 1, No. 2, Agustus 2021 hal. 178-189

DOI Artikel : 10.46306/jub.v1i2.34

\section{Gambar 9. Pendampingan Modul orang tua melalaui Home visit}

Berdasarkan berbagai kegiatan dan model yang dilakukan oleh tim pengabdian kepada masyarakat menunjukan bahwa dalam implementasi modul pembelajaran baik untuk guru, siswa dan orang tua berjalan dengan efektif dan efesien. Model yang digunakan menggunakan 3 model besar, yaitu workshop di sekolah, kunjungan dan pendampingan di rumah serta dengan strategi tutor sebaya.

\section{KESIMPULAN DAN SARAN}

Program pengabdian kepada masyarakat menghasilkan sebagai berikut. Pertama, Identifikasi masalah di Kabupaten Musi Rawas Utara model yang digunakan adalah melalui pembagian angket dan survei lapangan dengan 13 instrumen pertanyaan untuk mencari akar masalah pendidikan yang menentukan kegiatan perbaikan dan pengembangan pendidikan di Musi Rawas Utara. Kedua, pendampingan psikososial dilakukan dengan dua pola yaitu pola Home visit dimana pendampingan dilakukan dengan mengunjungi rumah orang tua dan siswa. Kedua, pendampingan di sekolah untuk mengikuti workshop dan konsultasi terkait masalah pendidikan saat pandemi covid-19. Ketiga, Pendampingan modul pembelajaran berupa dua komponen yaitu modul literasi dan numerasi kegiatannya berupa pendampingan kepada guru, orang tua dan siswa melalui kegiatan pembelajaran di sekolah dan kunjungan orang tua dan siswa untuk mengatasi learning loss.

\section{UCAPAN TERIMA KASIH}

Ucapan terima kasih terutama ditujukan kepada Kementerian Pendidikan Dan Kebudayaan, Direktorat Sekolah Dasar yang telah memberikan bantuan dana dalam pengabdian program kejar mutu. Ucapan terima kasih juga disampaikan kepada pihak-pihak yang membantu pelaksanaan pengabdian ini.

\section{DAFTAR PUSTAKA}

Aslamiyah, S., \& Nurhayati. (2021). Ekonomi Pasien Covid-1 9 di Kelurahan Dendang, Langkat, Sumatera Utara. Jurnal Riset Dan Pengabdian Masyarakat, I(I), 56-69.

Basar, A. M. (202I). Problematika Pembelajaran Jarak Jauh Pada Masa Pandemi Covid- 19. Edunesia : Jurnal Ilmiah Pendidikan, 2(I), 208-2 18. https://doi.org/I0.5 I276/edu.v2il.II 2

Coakley, J. (200I). Sport in Society: Issues and Controversies. New York: McGraw-Hill

Dikcy. (2020). Siswa, Orang Tua dan Guru Perlu Dukungan Psikososial Selama Pandemi Virus Corona. Diakses melalui https://www.voaindonesia.com/a/siswa-orang-tua-dan-guru-perlu-dukunganpsikososial-selama-pandemi-corona/5637255.html

Huong, L.T \& Jatturas, T.N. (2020). The Covid-I 9 Induced Learning Loss - What Is It And How It Can Be Mitigated? diakses melalui https://www.ukfiet.org/2020/the-covid-19-induced-learning-loss-what-isit-and-how-it-can-be-mitigated/ tanggal 25 Mei 2021

Kementerian Pemberdayaan Perempuan dan Perlindungan Anak. (2020). Buku Panduan Dukungan Psikososial Bagi Anak Korban Bencana Alam. Diakses melalui https://www.kemenpppa.go.id/lib/uploads/list/cd4df-buku-dukungan-psikososial.pdf

Khasanah, N., Sapti, M., \& Pangestika, R. R. (202I). Partisipasi Orang Tua Terhadap Pembelajaran Online di Rumah Ditinjau Dari Fase Kelas di Sekolah Dasar. Journal of Digital Learning and Education, I (0I), I0-2 I. https://doi.org/I0.52562/jdle.vli0I.3I

Murtadlo, M., \& Hazin, M. (2018). Model of Human Resource Management in Inclusive Education in East Java. 2/2, 54I-544. https://doi.org//0.2991/icei-18.2018.1I7

Nopembari, dkk. (Pelatihan Dan Pendampingan Penguatan Psikososial Melalui Pendidikan Jasmani Dan Olahraga Di Daerah Rawan Bencana. Diakses melalui Lumbung Pustaka UNY administration https://eprints.uny.ac.id/42396///Artikel\%20PPM.pdf

Noviana, I. (2010). Participatory action research: Peningkatan kesadaran masyarakat untuk menjadikan lingkungan yang bebas narkoba (Studi kasus di Komplek Permata, Jakarta Barat. In Jurnal Penelitian dan Pengembangan Kesejahteraan Sosial (Vol. I5, Issue 3, pp. 208-218).

Pratiwi, l., dkk (2020).Evaluasi Hasil Belajar Dari Rumah Tahun Ajaran 2020/202I, PROSIDING SEMINAR 
Pendampingan Psikososial dan Modul Pembelajaran Sekolah Dasar untuk mengatasi Learning Loss

Mufarrihul Hazin, Syarif Hidayat, Agus Suherman Tanjung, Ahmad Syamwiel, Abdul Hakim

Volume 1, No. 2, Agustus 2021 hal. 178-189

DOI Artikel : 10.46306/jub.v1i2.34

HASIL PENELITIAN TAHUN 2020; Kebijakan Berbasis Bukti untuk Memperkuat Kemerdekaan Belajar dan Ketahanan Budaya di Masa Pandemi Tahap I, Pusat penelitian kebijakan, I-9.

Syah, R. H. (2020). Dampak Covid- 19 pada Pendidikan di Indonesia: Sekolah, Keterampilan, dan Proses Pembelajaran. SALAM: Jurnal Sosial Dan Budaya Syar-I, 7(5). https://doi.org/10.15408/sjsbs.v7i5.15314

Yuliarisma, dkk. (202I). Peran Orang Tua Dalam Menyeimbangkan Psikologi Anak Pada Pembelajaran Matematika Masa Covid 19, Jurnal Review Pendidikan dan Pengajaran, 4(I), 70-75. http://journal.universitaspahlawan.ac.id/index.php/jrpp

Zamjani, I, dkk. (2020). Laporan survei pelaksanaan pembelajaran dari rumah dalam masa COVID-19: Pandangan Guru dan Kepala Sekolah. Jakarta: Pusat penelitian kebijakan. 